\title{
Modest Fashion: Diplomatic Creativity in Supporting Halal Tourism
}

\author{
${ }^{1}$ Arin Fithriana, ${ }^{2}$ Woro Nopitasari \\ 1,2 Budi Luhur University, Jakarta, Indonesia \\ 12Arin.fithriana@budiluhur.ac.id, ${ }^{2}$ woronopitasari@gmail.com
}

\begin{tabular}{|c|c|}
\hline Article Info & Abstract \\
\hline $\begin{array}{l}\text { Article History } \\
\text { Received:July 12, } 2018 \\
\text { Accepted: September } 30 \text {, } \\
2018 \\
\text { Keywords } \\
\text { Modest Fashion; Diplomacy; } \\
\text { Halal Tourism }\end{array}$ & $\begin{array}{l}\text { Halal has become a lifestyle that encompasses various aspects of life. The } \\
\text { acceptance of halal standards is not only dominated by countries with } \\
\text { Muslim populations, but also countries with a non-Muslim majority. This } \\
\text { acceptance is based on an understanding of the sustainability and impact of } \\
\text { halal products and services on whole life. Modest fashion Indonesia has } \\
\text { spread worldwide and represents halal lifestyle. Modest fashion has become } \\
\text { a tourist attraction and helped establish good relationship between } \\
\text { Indonesia and world fashion. In this case, modest fashion serves as a tool of } \\
\text { diplomacy. Unfortunately, modest fashion potency as supporter for tourism } \\
\text { development has not been integrated well. This paper explores how modest } \\
\text { fashion as a tool of diplomacy through creativity supports tourism. This is } \\
\text { because the existence of tourism encourages multiplayer effects for other } \\
\text { economic activities. Indonesia's cultural diversity and local wisdom should } \\
\text { be an integral part of Indonesia's halal tourism. The contribution of fashion } \\
\text { modest as a tool of diplomacy in creative industry to support halal tourism is } \\
\text { analyzed using qualitative method through secondary data. The data show } \\
\text { the development and acceptance of Indonesian modest fashion as well as its } \\
\text { creativity utilizing culture and local wisdom has been widely accepted } \\
\text { globally, but has not been fully exploited yet. Modest fashion has established } \\
\text { good relationship between international actors. Integrating modest fashion } \\
\text { with local wisdom and culture encourages the exploration of tourist } \\
\text { destinations that are expected to encourage other halal standards in } \\
\text { tourism. Ultimately it is expected to have a positive impact on sustainable } \\
\text { development. }\end{array}$ \\
\hline $\begin{array}{l}\text { Support by: } \\
\text { do) Crossref }\end{array}$ & This is an open access article under the CC-BY-SA license \\
\hline
\end{tabular}

\section{INTRODUCTION}

The current halal tourism trend is not only the monopoly of Muslim countries, but also non-Muslim countries. This trend is driven by an increase number of Muslims in the world, Muslim diaspora especially from conflict areas and the conformity of some provisions in industry or trade with halal provisions. Indonesia, as a Muslim majority country, halal provisions have also become part of the Indonesian government's policy with the halal certification body and the Halal Product Assurance Management Agency (BPJPH) under the Ministry of Religious Affairs. Halal provisions developed by Indonesia have become the world reference for developing halal products. Indonesia is also the initiator of the World Halal Forum in 2013 which held in Jakarta. Indonesia has a dream to become the world's halal reference country.

Today's tourism industry is also increasingly complex, not just offering tourist destinations with natural beauty, entertainment, cultural heritage or celebrations, but also has been integrated with some areas such as sports, health, education and religion. Such tourism package which offered by a Thailand travel agent, offers some destinations from the entertainment, fell the massage for health being, how to cultivate 
pollen bee, to cook tom yam, visit the temple and religious activity and adventure with elephants. So that, tourism requires its own creativity by maximizing the wealth, genius and wisdom of local values to be more competitive. As one of the creativity that Indonesia has done is in the fashion industry. Indonesia Fashion developed quite rapidly with the high fashion show that is done regularly every year through Jakarta Fashion Week (JFW) which involves young Indonesia designer. The existence of political reformation and political openness also gives some opportunities for Moslem to show their Islamic identity such through Muslim fashion, so the demand for Moslem wear is increasing, even it has become fashion trend since Muslim fashion show is held. The presence of this fashion show has also become an international concern with the presence and involvement of foreign designers in the show. This activity became part of Indonesia's tourism destination which awaited by some fashion designer, observers, fashion blogger, media and even travel agents. In addition, the Indonesia designer in Muslim fashion line is also actively involved their masterpiece in both domestic and overseas performances. Unwittingly, by joining the performances, designer bring around their own values which communicated to the global audience, whether it is local values of cultural diversity and wealth of Indonesia and of course religious values, in the form of Islamic sharia.

As mentioned before, that the development of tourist destinations today has been integrated with several sectors to increase its competitive value and maintain its existence as a sustainable tourist destination. The high number of Muslim populations with cultural diversity, the development of Muslim designers, the presence of certification bodies and the managers of halal products owned by Indonesia government does not necessarily put Indonesia as a country with a competitive advantage on halal tourism in global area. The reality is, that the Indonesian government too late to realize any potential that could be a competitive advantage become one of the reasons for this condition. In addition, the existence of state awareness for non-Muslims countries to meet the needs of Muslim travelers become a challenge that must be faced by Indonesia. Based on some of these phenomena, one of the things that can be developed to support the development of Indonesian halal tourism is fashion, in this case is the Muslim fashion. Indonesia Muslim fashion has brought the Indonesian designer to several international fashion show. What these designers have done is indirectly as part of the promotion of Indonesian cultural diversity. In international relations, this promotion is part of public diplomacy conducted by non- state actor. So that the focus of analysis is how the relationship between Muslim fashion and diplomacy and how its role in supporting Indonesia's halal tourism. Furthermore to explain the analysis, the term of Muslim fashion replace by modest fashion. Terminology of modest fashion is more readily accepted and more widely covered in industry, and does not elicit certain stereotypes.

\section{METHOD}

The contribution of fashion modest as a tool of diplomacy in creative industry to support halal tourism is analyzed using qualitative method through secondary data.

\section{RESULTS}

\section{Modest Fashion Indonesia in Indonesia Diplomacy}

Indonesia Modest fashion developed into a part of the Indonesian fashion industry. This development is growing rapidly with the support of the increasing acceptance and fashion trends of Muslims and modest fashion in the world. The development of 
technology and globalization also support the development of Indonesian modest fashion. This have been discussed by Siti Dewi Aisyah in The Role Of Social Media for The Modest Fashion Movement in Indonesia (Dewi, 2017) that the tren of modest fashion consumer demand, not only by Muslims, but also non-Muslims through communication in social media and internet. This development also encourages the emergence of new designers in modest fashion. Even leading brands are also contributing in modest fashion modest such as Adidas and Nike which develop sports equipment or accessories for hijaber, or brand Zara, Mango, DKNY, Oscar de la Renta which outfit with design that can be used by hijaber. The involvement of leading brands in the modest fashion line shows that the brand accepts the diversity and different ways of looking in dress up. That polite and bunged up clothing not only belong to Muslim groups, or otherwise Muslim clothing can be used by everyone. From the economic side, of course, the leading brand does not want to vain the opportunity to gain profit. The existence of Muslim who fashion-conscious is a target of consumer in modest fashion. Modest fashion designers are also not only come from countries with Muslim populations. Zamzam Zalila, German designer, Imaan for Gulshaan from France label Huw Roman, or Hana Tajima for Uniqlo Japan. Japanesse designers who brought the modest fashion in her work. Japan is not a country with a Muslim majority Muslim. What this Tajima did has also received support from the Japanese government, as evidenced by the efforts made by the Japanese government in implementing the halal concept in an integrated manner. Can be said here, the designer progress at international level can be a media to communicate the purpose and value which adopted. Or in other words, designers have done the diplomacy to convey what is the international actor goals, it can bet state, corporation or group.

Diplomacy is a way to influence the policies, behaviors and other actor's way of thinking as desired to achieve the goals. Formally diplomacy is implemented by the government. Globalization and technological developments influence the nation state's diplomacy techniques. It takes the involvement of other actors to be more synergic in achieving national goals. Multitrack diplomacy is a conformation of diplomacy that utilizes saveral channels to facilitate the achievement of nation state objectives, including the involving of non-formal actors or public including bussiness people, designer, academic, artis etc. Public involvement, Whether realized or do not have an important role in the achievement of national interests. The term public diplomacy emerges with the involvement of non-state actors to facilitate the achievement of national interests, especially on low politics issues. This is the point of the relationship between modest fashion and diplomacy. Modest fashion is a part to promote Indonesia through their creation which being displayed and the sustainability of the activity.

Indonesia Modest fashion has experienced rapid development, even in domestic trade has been expanded and has been able to increase communities's incomes. According to President Joko Widodo, modest fashion has a bright future because we live in the era of technology, the era of openness, the era of competition, and lifestyle. Which modern fashion and has traditional elements will be even better if supported by technology such as through social media that will make a development in fashion. The way that can be done is to advertise the goods into exchange rates. So the modest fashion becomes a trading commodity. Specialization in the modest fashion also increased to become one of the commodities of the fashion business. The business is one of Indonesia's creative industries that has the potential to be developed as an industry that has global competitiveness (kemlu.go.id, 2017). Even in 2017 Indonesia has economic value of 166 trillion Rupiahs where 54 trillion Rupiahs donated from modest fashion sector. The development of Indonesian modest fashion cannot be 
separated from the role of designer. The first generation of Indonesia appeared in the 1980s by Ida Royani and Itang Yunaz. Undeveloped technology plus closed social political conditions become obstacles in its development. Fashion shows event are also still limited to Asian countries. The next generation in the 1990s was Irna Mutiara, Hannie Hananto, Monika Jufry and Najua Yanti who later founded Hijabers Mom Community in 2011. In this generation, modest fashion became more accepted and evolved until the third generation that had the opportunity to promote modest fashion through social media technology that is Blog, Facebook, Twitter and Instagram. They are Ria Miranda, Jenahara and others from the third generation who also formed the Hijabers community in 2010 (Dewi, 2017). The use of the term hijaber is simple because it uses hijab to complete the fashion used. While fashion has a coverage not just clothing, but everything that is used from head to toe, including outer clothing, undergarment, and complement either the use as a decoration (accessories) or also has a useful value for the user (Hadijah, 2014). Given the term concept of fashion, the modest fashion cannot stand alone without the support of other complementary products.

Modest fashion Indonesia develops through creativity by utilizing diverse Indonesian culture. Modest fashion is part of the creative economy that contributes greatly to increased value added, job creation, as well as exports in various countries. Creative economy itself is one of the sectors that are expected to be a new power of the national economy in the future, along with the increasingly degraded natural resources annually (bekraf.go.id, 2017). In 2015 Creative Economic Bureau (Bekraf) contributed export value of 19.4 billion US dollars (12.88\%), up from the previous year. One in the creative economic (Ekraf) subsector is fashion and being the second largest contributor to Gross Domestic Product (GDP) after culinary sector. Even for the export of fashion accounted for the highest GDP, followed by culinary and craft. Modest fashion became part of the fashion subsector. Modest fashion Indonesia has a characteristic that cannot be imitated by any country. Modest fashion also has the potential mode to be developed as an industry that has a global competitiveness considering fashion enthusiasts have increased and the recognition of the creativity of Indonesian designers globally. After the development of fashion and the recognition of modest fashion designers of Indonesia that the designers are doing International fashion show, becoming champion in fashion design competition Muslim magazine, has its own community in Indonesia and its production into one sub-sector creative industries. Government recognition can be seen from the existence of cross-sectoral or ministerial involvement with regard to the development of modest fashion as Bekraf aims to develop fashion with its creative economic outlook. The Ministry of Commerce placed the trade side of the industry for then the Ministry of Industry focused on a larger industrial market, but still helped the small and medium industries for the fashion modest sector. Next the Ministry of Tourism is in charge of marketing modest fashion products as part of tourism. The Ministry of Commerce has activities in the fashion industry to fully support in this industry such as conducting fashion shows, providing the special modest fashion exhibition zones, including providing education and training to modest fashion industry players. Fashion show events held are Jakarta Fashion Week and Muslim fashion festival held to support the fashion creative industry and bring forth to new designers who are ready to enter the retail world. Not only that the government supports the results of modest fashion design to enter the global market by following the international fashion show event. The result of this fashion show is followed by trading activities that supported economic value. 
To meet global demand, modest fashion are tailored to International consumers who are more interested in fashion designs that will not always use hijab but also to be used by non- Muslims such long wear or Abaya clothing which will still look nice and fashionable when used. Abaya itself is a Muslim fashion commonly used for Middle Eastern women, including in North Africa and the Arabian Peninsula (bp-guide.id, 2018). Other clothing such as long dress and rather wide (not too fit in Body), also long knee-length clothing and then combined with long pants or long skirts. Clothing favored by Australians prefers long or loose cut outfits and outwear (riuaonline.com, 2015). While consumers of Japan and Southern Europe prefer clothing with organic materials that produce natural colors (kemendag.go.id, 2014). But for some American retailers are more issued a hijab design in the form of sports used atlet or used for daily life for Muslims who live in a minority country.

An example of the modest fashion as part of diplomatic form is the participation of Indonesian designers at New York Fashion Week (NYFW) which was held on September 7 , 2017. The event is one of the world's main fashion reference and become a forum for designers from America and around the world to show their fashion and to reach the international market. However, Indonesian designers show their fashion clothing with modest fashion and hijab themed "Indonesian Diversity" or "Cultural Diversity". Indonesia's cultural diversity and natural resources is managed by designers, promoted through modest fashion, and supported by the Indonesia government. A fashion show which held in overseas is an activity that brings cultural values to show Indonesia's "diversity" to achieve global competitiveness. Fashion show became an important activity in improving the relationship between countries. That's because cultural values are more easily accepted and understood by almost the entire world community. This diversity can be seen from the creation has been shown such as by Dian Pelangi incorporating the idea of "Human of New York" with traditional Indonesian materials such as batik material and songket. While Vivi Zubedi shown the design of hijab and colorful abaya collection with patterned batik. Indonesian designers who follow the New York Fashion Week event are not only modest fashion designer but also all designers such as Barli Asmara, Catherine Njoo, Riza Assegaf and Farah Shahab from Doris Dorothea and Melia Wijaya. Barli shown features elegant and elegant designs dominated by white in her outfit. Catherine Njoo shown the nuances of traditional Indonesia Balinese batik filled with gold and black motifs. Equipped with some elegant headdresses, gold masks and ethnic jewelry with modern designs (voaindonesia.com, 2017). Melia Wijaya shown contemporary designs inspired by Indonesian folklore. While designer Riza Assegaf and Farah Shabab are bag designer with their bag brand named Doris Dorothea.

The event includes a refreshing change from the usual fashion week trend. The event will contribute in supporting Indonesian diplomacy to foreign countries so as to enhance the image of Indonesia that still uphold the culture and Islamic values without eliminating the uniqueness and originality of materials from various regions. The real shape of the international and national event is one of the support of the Government of Indonesia, where some ministries join to promote Indonesian fashion, especially the Ministry of Commerce. The object of designers featuring modest fashion in International event is an active woman who needs simple clothes in order easy to move, comfortable and modern. The main consumers for a designer are women from middle and upper social class, especially urban communities in big cities (kemendag.2014). So through modest fashion, public diplomacy is formed to influence the attitude or public opinion with the event held. Designers interact not only with the domestic public but with international actors. Public diplomacy activities through international and national 
events have been developed and considered effective to build a positive image of Indonesia is reflected through international- quality fashion products.

But for Indonesian designers such as Vivi Zubedi performing fashion show in America as a public diplomacy as part effort for the Muslim world especially in America, through modest fashion activity to improve the image of the Muslim community in the world and eliminate the issues of islamophobia. The struggle for the Muslim community of the world is just the same as that of the Indonesian Muslim community. From the very beginning of modest fashion which developed from Indonesia so many Muslim communities voiced their understanding of the modest fashion to be received from both the public and the government. Designers became the main character to change public opinion in a misunderstanding of fashion and voice how to become a Muslim in a country that forbids it. As is the case in a predominantly non-Muslim country.

\section{Indonesia Halal Tourism}

The Implementation of halal concept has become a trend, not only on products in the form of goods but also services, including tourism. Measuring the implementation of halal concept in some conditions still requires in-depth study. This is also confirmed by Michele Carboni in article "Halal tourism de facto: A case from Fez", that there is still no clarity with regard to halal tourism standards that can be recognized globally. Similarly, the implementation of halal radically potentially leads to prejudice and stereotypes against Muslim groups (Carboni, 2016). The uncertainty of this standard is because in tourism sector, the actors involved vary greatly. In the tourism providers such as local genius and local wisdom which is the attraction in tourism has its own value that is sometimes different from the value in Islamic sharia. Similarly, with the various tourist, the restrictions that are too tight can cause tourist appeal decreased. This condition is highlighted in Hatem El-Gohary's article, "Halal tourism, is it really Halal?" because halal tourism is different from religious tourism (ElGohary, 2016). On the other hand, the diaspora of Muslim groups including refugees and the awareness of Muslim tourists in selecting destinations encourage non-Muslim destinations countries to develop Islamicfriendly tours including fulfillment of halal standards. This phenomenon becomes a challenge for the country with the Muslim community that for the next few years will face the competition of halal tourism with non- Muslim countries as in the study of Mohamed Battour and Mohd Nazari Ismail, "Halal tourism: Concepts, practices, challenges and future (Battour, 2016). So in applying the concept of halal tourism required deep study and formulation of its own in relation to the benefits of tourist destinations.

Although Indonesia is a country with a Muslim majority, a different understanding of halal standards has the potential for conflict among fellow Muslims. Including when the implementation of the concept of halal is also radically potentially conflict with nonMuslim groups. Recognizing this, the Indonesian government is still reviewing the scope and implementation of Indonesia's halal tourism. Ministry of Tourism of Indonesia (Kemenpar) realize the importance of halal tourism or family friendly tourism to improve the country's tourism industry. Activities undertaken are marketing potential family friendly tourism to the perpetrators of the tourism industry. Halal tourism will be a big driver for national income in 2020. The competitiveness of halal tourism destinations in Indonesia is also increasing globally. In 2016 Indonesia is in third ranked in the rating of Global Muslim Travel Index (GMTI) after Malaysia and UAE. And in 2019, Indonesia is targeting number to be number one in the world. there are ten programs prepared by Ministry of Tourism to accelerate the development of halal tourism in Indonesia. Three of them become Top 3 Programs, such as preparation of 
sellers and the manufacture of superior Halal tour packages, branding, Public Relations, and promotion (print and electronic marketing tools) and digital tourism. Indonesian Tourism Minister Arief Yahya, who attended the 2015 GMTI press conference, said Indonesia is still focusing on two halal tourism destinations in Indonesia besides West Nusa Tenggara (NTB), in this case Lombok, are West Sumatra and Aceh. Indonesia Halal Expo (Indhex) 2013 and Global Halal Forum which held on 30 October - 2 November 2013 by President of Islamic Nutrition Council of America, Muhammad Munir Caudry, explained that, "Halal tourism is a new concept of tourism. This is not religious tourism like umroh and performing the pilgrimage. Halal tourism is tourism that caters to holidays, by adjusting holiday style according to the needs and requests of Muslim traveler".

Indonesia's halal tourism is part of Indonesian tourism that promotes the diversity and natural beauty of Indonesia. Brand positioning Indonesia tourism is Wonderful Indonesia which is the promise of Indonesian tourism to the world. The word "Wonderful" contains the promise that Indonesia is rich with wonder, from both human and natural aspects, which touching the heart and promises a pleasant new experience for tourists. A brand positioning statement is an important part of communication and is an expression of the brand itself. This statement not only distinguishes Indonesia from other tourist destinations. But also to the brand that has many variations of products, should be given a concept of guidance that can separate these products and create different insights from each wonders, so that people can feel the story behind their existence. The thematic wonders experience have 5 thematic communication pillars created according to the destination and or experience in Indonesia, there are the Natural Wonders experience describes things like nautical \& marine, mountainous and green areas, used when communicating the natural beauty of Indonesia. Sensory Wonders experience describes things like food \& beverage, health, and entertainment. used when communicating activities in Indonesia that can be felt by the 5 senses of the human body. Cultural Wonders experience describes things like art, culture, and heritage, used when communicating the greatness of tradition and cultural activities in Indonesia. Modern Wonders experience describes things like urban life, technology, and transportation, used when communicating the greatness, modernity and progress of Indonesian civilization, Adventurous Wonders experience describes things like sport, adventure, and exploration, used when communicating greatness, adventure, and uniqueness of sports activities in Indonesia. With this diversity shows that, the implementation and coverage of Indonesian halal tourism is also very diverse (Ministry of Tourism, 2017). For the sustainability of halal tourism in Indonesia, the Ministry of Tourism decided on halal logo of Tourism Indonesia and Indonesian Halal Tourism logo. The logo is intended to accelerate the marketing and promotion of Indonesian Halal Tourism. This logo applies nationally and internationally which in its use must include the logo of Indonesia at Indonesian Halal Tourism and logo of Pesona Indonesia on Indonesian Halal Tourism logo.

Development vision of Ministry of Tourism using the Vision of the President of the Republic of Indonesia period 2015-2019 namely the realization of a sovereign Indonesia, independent, and personality based on mutual cooperation. This is in line with the mission of developing competitive tourism destinations, developing products and services of the international tourism industry and responsible for the environment, developing synergistic and superior tourism marketing, and developing government organizations, both central and local government, private and public. Based on the vision and mission of the Ministry of Tourism in 2015-2019, the goal is to improve the quality and quantity of tourism destinations, realizing the tourism industry that is able 
to motivate the national economy to get together with other Asian nations, and maximize the productivity of tourism marketing performance. The objective is to run with the strategic objectives of the Ministry with the increasing quality of tourism destinations, increased investment in tourism sector, increasing tourism contribution, and increasing number of domestic and foreign tourists.

The development of halal tourism in Indonesia is regulated by the Minister of Tourism and Creative Economy No. 2, of 2014 concerning Guideline of Sharia Business Operations, article 1, is meant by Islamic law as stipulated by fatwas and or approved by Majelis Ulama Indonesia (Indonesia Ulama Council). The syariah term began to be used in Indonesia in the banking industry since 1992. From the banking industry to other sectors, syariah insurance namely Takaful, shariah pownshop, syariah hotel, and syariah tourism. (Regulation is revoked through RI Minister of Tourism Regulation No. 11 of 2016). Tourism development is based on the principle embodied through the implementation of the tourism development plan with respect to diversity, uniqueness, and tourism development covering the tourism industry, tourism destinations, marketing, and tourism institutions.

Indonesia's current halal tourism development that has become a reference for other regions is Lombok. Lombok has experienced an increase in the number of tourists both domestic and international. but there are still some obstacles in its development related to some conditions. First, the regional tourism industry is still unstable with the issue of crime and fights. This is due to the unstable condition of the community in the region. The second problem is the commitment of local governments to the development of tourism is less than optimal. The gap between (Das Sein) and (Das Sollen) is clearly visible in this situation. Often many attractions or tourist destination are not managed properly or even not managed at all in accordance with local regulations. Each region certainly has different potential, local governments should also make their own arrangements according to regional needs so that existing potentials can be utilized properly. Or local government can involve private parties. The third problem is simply relying on nature as the main attraction. The fourth problem is the lack of public awareness of the understanding of environmental comfort. This problem is not impossible also faced for other areas considering some tourist destinations have almost the same conditions.

\section{Modest Fashion Supporting For Halal Tourism}

All this time, the product that is often offered in tourism is food. Halal food review is a part of tourism promotion. This is conveyed by Joan C. Henderson in the article "Halal food, certification and halal tourism: Insights from Malaysia and Singapore" (Henderson, 2016). Whereas in tourism not only serves food but also other creation on tourist attraction. Cultural resource that is implemented in fashion works can also be part of tourism promotion. The recognition of batik as a cultural heritage by UNESCO became an example of non-food products become an effective part in tourism. Products use batik theme to be one of the tourist target as a souvenir. Batik is also a branding image of Indonesia, so when saying batik, then in the mind that flashed is Indonesia. Promotion on batik is often a fashion show and equipment such as bags, shoes, and accessories.

Creating batik through various products directly increases the economic value of batik. Various creations of batik become part in tourism promotion. For example, with some batik centers in Pekalongan which become tourist destinations both locally and internationally, even international buyers are promoting Pekalongan as a cultural tourism destination for not only displaying batik creations, but developing batik tourist 
destinations that can be followed by tourists. The result of Indonesian textile culture is not just batik. Various cultures produce a variety of textiles with their own philosophical value. Like Balinese songket, Tapis of Lampung, Batak Ulos, various woven and jumputan is a textile culture that has the potential to bring around tourists.

Through designers who utilize textile materials as part of their modest fashion works, it becomes a consumer appeal. Consumer interest does not stop there. The hope of course there is a follow-up of the modest fashion show. Through modest fashion, Indonesia opened outlets or boutiques in several countries that show the creativity of Indonesia. For examples the sustainability of New York Fashion Week, the work of Indonesian designers can be seen in Indonesia Galery. Even, at the performance, as if the Trump policy about Islamophobia is broken. The enthusiasm and public acceptance of the United States towards modest fashion shows that Islam is not as scary and dangerous as it is thought. Travel warning directed to the country with the Muslim community also seemed to disappear. It can be said that the participation of fashion designer fashion designer Indonesia in the international arena became a medium to change the way of view and how other actors think of Indonesia. Even at the event, there are American designers who display modest fashion in the event the New York fashion week is Marc Jacobs who is an American fashion designer. Marc presented spring / summer collection of 2018 with a turban model in September 2017 (Astuti, 2018). The collection follows the current fashion industry, where the Middle East and Asia markets are designing collections in fashion modest. This shows that modest fashion is not only the attraction of the Muslim group but also the wider audience.

Indonesia Designer became a highlight after appearing at the New York Fashion Week event where the event is one of the main fashion reference of the world and become a place for designers from America and around the world to display clothing to reach the international market. However, Indonesian designers show fashion clothing with modest fashion and hijab themed "Indonesian Diversity" or cultural diversity. Indonesia's cultural diversity and natural wealth are managed by designers, promoted through fashion modest, and supported by the government through BEKRAF. A fashion show held overseas is an activity that brings cultural values to show Indonesia's "diversity" to achieve global competitiveness. The event is an important activity in improving relations between countries. That's because cultural values are more easily accepted and understood by almost the entire world community.

As mentioned earlier that the designers are using traditional fabrics and natural resources of Indonesia, such as pearls, gold, silver which is the main attraction. The creation of Indonesian designers in the form of modest fashion is a national asset that can support the achievement of national interest. Public diplomacy does not only prioritize state assets but also to achieve national interests. Designers become the main character to achieve the national interest by displaying the art of Indonesian culture to the world through the work of the fashion industry. The progress of the Indonesian fashion industry is supported by the diversity of Indonesian culture that inspires designers. Designers not only want to put forward the culture and aesthetics but also the economic value of typical Indonesian design materials such as batik, woven, songket, jumputan and others fabric for public diplomacy. Public diplomacy activities undertaken internationally through modest fashion aims to attract tourists to the fashion that is displayed, thus encouraging the occurrence of exports to international consumers.

Indonesia Designer has made public diplomacy by introducing various Indonesian culture through modest fashion, so the next step is to prepare tourist destinations where the cultural diversity comes from. For example, when Helen Dewi Kirana uses 
Jumputan textile in her high fashion for muslim wear at NYFW, so some areas with textile culture of jumputan can seize this opportunity to be integrated in tourism. As batik and woven with different patterns in each region, as well as with jumputan like Java, Banjarmasin, Palembang and Bali, each region also has its own style, variety, technique and philosophy. This cultural resources can be utilized to attract tourists. The utilization of cultural resources should be integrated. Cooperation by various parties, both the ministry of tourism and the Creative Economy, the Ministry of Foreign Affairs, the Ministry of Trade and some other ministries to encourage the establishment of an integral halal tourism destination. The modest identity of fashion that is increasingly attached to Indonesian designers is an opportunity for Indonesia to further develop an integrative halal tourism and involve many actors without removing the diversity of cultures, tribes and religions that flourish in Indonesia.

\section{CONCLUSION}

Modest fashion role in the international fashion arena has made Indonesia as a country that is identical with modest fashion. The diversity of cultures brought in the modest work of Indonesian fashion designers helped bring about a change of perspective towards Islam. That Islam through modest fashion can be able to bridge the various differences that exist. This modest fashion involvement supported by the Indonesian government is a form of public diplomacy to achieve national interest. The economic value obtained by modest fashion is expected to encourage the achievement of other economic value such as the development of halal tourism destination by utilizing local creativity potency (local genius) in an integrative way. As a majority Muslim country, fashion modest become part of primary requirement in dress which is not only interested by Muslim but also non-Muslim as both consumer and producer.

\section{REFERENCES}

[1] Dewi, Siti Aisyah, (2017), The Role Of Social Media for The Modest Fashion Movement in

[2] Indonesia, taken from Thesis, accessed at 5 April 2018

[3] News from Kemlu, Potency of Creative Industry on Indonesia Muslim Fashion in Istanbul in Bahasa, Berita dari Kemlu.go.id, (2017), Potensi Industri Kreatif Busana Muslim Indonesia di Istanbul, accessed at 9 April 2018, News from Kemlu, Potency of Creative Industry on Indonesia Muslim Fashion in Istanbul.

[4] Hadijah, Idah, (2014), Efforts to Increase Export Drive of Fashion Industry in Globalization Era, in Bahasa Upaya Peningkatan Export Drive Industri Fashion di Era Globalisasi, taken from journal.um.ac.id, accessed at 31 March 2018

[5] Bekraf, (2017), Statistical Data and Results of Creative Economy: Cooperation between Creative Economy Agency and Central Bureau of Statistics, in bahasa Data Statistik dan Hasil Ekonomi Kreatif : Kerjasama Badan Ekonomi Kreatif dan Badan Pusat Statistik, taken from bekraf.go.id, accessed at 15 April 2018

[6] 9 of the Latest Arabic Muslim Clothes Are the Best Recommendations for Those of You Who Want to Appear Shari'i in Bahasa 9 Baju Muslim Arab Terbaru ini Adalah Rekomendasi Terbaik Bagi Anda yang Ingin Tampil Syar'i , taken from https://bpguide.id/AXL8U9nQ, accessed at April 2018

[7] Ningsih, Winahyu, (2015), Who would expect Muslim Clothing in demand in Australia, in Bahasa Siapa Sangka Busana Muslim diminati di Australia, taken from http://www.riauonline.co.id/life-style/read/2015/09/09/siapasangka-busana-muslim- diminati-di-australia , accessed at April 2018 
[8] Roesfitawati, (2014), Indonesia Fashion Week 2014, taken from http://djpen.kemendag.go.id/app frontend/admin/docs/publication/398142105677 6.pdf, accessed at April 2018

[9] Rukmananda, Naratama, (2017), Hijab and Batik Bali Open New York Fashion Week The First

[10] Stage, in Bahasa Hijab dan Batik Bali Buka Ajang New York Fashion Week The First Stage, Voa Indonesia https://www.voaindonesia.com/a/hijab-dan-batik-balibuka-ajang- new-yorkfashion-week-/4021336.html, accessed at 20 Mei 2018.

[11] Carboni, Michele, M'hammedIdrissi Janati, Halal tourism de facto: A case from Fez Tourism Management Perspectives, Volume 19, Part B, July 2016, Pages 155-159 https://doi.org/10.1016/j.tmp.2015.12.007Get rights and content

[12] El-Gohary, Hatem Halal tourism, is it really Halal?, Tourism Management Perspectives, Volume 19, Part B, July 2016, Pages 124-130, https://doi.org/10.1016/j.tmp.2015.12.013Get rights and content

[13] Battour, Mohamed Mohd Nazarilsmail Halal tourism: Concepts, practises, challenges and future, Tourism Management Perspectives, Volume 19, Part B, July 2016, Pages 150-154, https://doi.org/10.1016/j.tmp.2015.12.008Get rights and content

[14] Ministry of Tourism Republic of Indonesia, Brand and Design Application Guidelines, Indonesia, 2017, p. 14-19 